\title{
Identifikasi Hasil Belajar Siskomdig Karena Efek POE Dibandingkan PRP Pada Siswa SMK
}

\author{
Ines Rendra Kusuma \\ Teknik Elektro, Universitas Negeri Malang, Indonesia \\ inesrendra@gmail.com \\ Setiadi Cahyono Putro \\ Teknik Elektro, Universitas Negeri Malang, Indonesia \\ setiadi.cahyono.ft@um.ac.id \\ Dila Umnia Soraya \\ Teknik Elektro, Universitas Negeri Malang, Indonesia \\ dila.umnia.ft@um.ac.id
}

(Diterima: 09-Oktober-2018; di revisi: 20-November-2018; dipublikasikan: 29-Desember-2018)

\begin{abstract}
The goals of this research are to find the difference of mean the cognitive and psychomotor learning outcome Simulation and Communication Digital due to implementation of POE learning model compare to learning model PRP . This research is using quasi experimental design through the type of Non-Equivalent Control Group Design. The hypothesist will be tested using Independent Sample of T-test. The result of this research showed that the mean difference test of students' learning outcomes in the cognitive obtained a significance of 0.006 , while the psychomotor learning outcomes obtained a significance of 0.000 . Based on the results of the average difference, the learning model that is superior to cognitive and psychomotor is the POE learning model.
\end{abstract}

Keywords: learning outcome, POE learning model, PRP learning model, Digital Simulation and Communication

\begin{abstract}
Abstrak: Tujuan penelitian untuk mengetahui perbedaan rata-rata hasil belajar ranah kognitif dan psikomotor Simulasi dan Komunikasi Digital (Siskomdig) karena penerapan model POE dibandingkan dengan model pembelajaran PRP. Penelitian ini menggunakan rancangan eksperimen semu dengan tipe Non-Equivalent Control Group Design. Uji hipotesis menggunakan Independent-Sample T Test. Hasil penelitian menunjukkan bahwa uji perbedaan rerata hasil belajar siswa pada ranah kognitif diperoleh signifikansi 0,006, sedangkan hasil belajar ranah psikomotor diperoleh signifikansi 0,000. Berdasarkan hasil perbedaan rerata tersebut, model pembelajaran yang lebih unggul pada ranah kognitif dan ranah psikomotor yaitu model pembelajaran POE.
\end{abstract}

Kata kunci: hasil belajar, model pembelajaran POE, model pembelajaran PRP, Simulasi dan Komunikasi Digital

Copyright (C) 2018 Universitas Negeri Makassar. This is an open access article under the CC BY-NC-ND license (http://creativecommons.org/licenses/by-nc-nd/4.0/).

\section{PENDAHULUAN}

Simulasi dan Komunikasi Digital (Siskomdig) merupakan salah satu mata pelajaran yang dipelajari di SMK kelas X pada kurikulum 2013 revisi. Simulasi dan Komunikasi Digital disajikan dalam bentuk teori dan praktik. Tujuan mata pelajaran ini adalah memberi bekal siswa agar mampu 


\section{9 | Jurnal Psikologi Pendidikan \& Konseling Vol. 4 No. 2 Desember 2018}

mengkomunikasikan suatu konsep melalui media digital.

Bedasarkan hasil observasi pada mata pelajaran Simulasi dan Komunikasi Digital pada kelas X TKJ di SMKN 10 Malang, ditemukan beberapa permasalahan. Permasalahan pertama, model pembelajaran yang diterapkan guru sama pada semua materi. Hal tersebut membuat siswa jenuh. Kedua, apabila siswa merasa jenuh, maka siswa akan melakukan aktivitas lainnya.

Ketiga, pada saat melakukan praktikum siswa tidak menggunakan jobsheet yang memuat langkah-langkah praktikum secara detail dan rinci. Keempat, hasil belajar siswa pada ranah psikomotor rata-rata sudah mencapai KKM, namun pada saat ditanya satu per satu banyak siswa yang belum paham materi. Kelima, hasil belajar siswa pada ranah kognitif masih banyak yang dibawah KKM. KKM yang ditetapkan di SMKN 10 Malang adalah 75, sedangkan hanya $10 \%$ siswa yang mampu mencapai nilai di atas KKM.

Beberapa permasalahan diatas akan berpengaruh terhadap ketuntasan belajar siswa tentang materi yang telah diberikan oleh guru. Penelitian ini penilaian hasil belajar siswa difokuskan pada ranah kognitif dan ranah psikomotor, karena dalam pembelajaran Simulasi dan Komunikasi Digital akan mempelajari teori yang berisi konsep awal, kemudian dilanjutkan dengan kegiatan praktikum. Sehingga dengan penanaman konsep awal yang kuat akan menjadikan dasar yang baik untuk proses pembelajaran pada tahap selanjutnya.

Berdasakan permasalahan yang telah dipaparkan, maka diperlukan suatu model pembelajaran yang menarik dan dapat membuat siswa aktif selama proses pembelajaran, sehingga dapat meningkatkan hasil belajar siswa. Model pembelajaran yang dibutuhkan yaitu model pembelajaran yang membangun pengetahuan awal siswa.

Model pembelajaran yang dapat diterapkan sesuai dengan solusi permasalahan diatas yaitu model pembelajaran POE (Prediction, Observation, And Explanation) dan PRP (Practice Rehearsal Pairs). Kedua model pembelajaran ini diharapkan dapat membuat siswa akan lebih berpartisipasi aktif dalam kegiatan pembelajaran serta dapat meningkatkan hasil belajar siswa.

Model pembelajaran POE adalah model pembelajaran yang diperkenalkan oleh White dan Gustone. Menurut White \& Gustone (dalam
Muna, 2017) model POE dikembangkan untuk menemukan kemampuan memprediksi siswa dan alasan mereka dalam membuat prediksi tersebut mengenai gejala sesuatu yang bertujuan untuk mengetahui konsep awal yang dimiliki siswa. Siswa dilatih untuk aktif terlebih dahulu mencari pengetahuan menggunakan sumbersumber yang dapat memudahkan dalam pemecahan masalah.

Kriteria pembelajaran POE menurut Permatasari (dalam Muna, 2017) yaitu: (1) mempunyai prosedur yang sistematis sesuai metode ilmiah; (2) kegiatan pembelajaran berbasis laboratorium; (3) kegiatan pembelajaran di mulai dari sudut pandang siswa; dan (4) pembelajaran bersifat konstruktivistik. Menurut Wardoyo (dalam Putro, 2016) pembelajaran konstruktivistik merupakan proses pembelajaran yang menjadikan siswa sebagai pusatnya, siswa yang berusaha untuk mendapatkan informasi untuk pengetahuanya, sedangkan pengajar berperan sebagai mediator dan fasilitator.

Model pembelajaran POE merupakan proses pemecahan masalah yang dilakukan oleh siswa melalui tahap prediksi (predict), pengamatan (observe), serta penjelasan terhadap hasil (explain) (Suparno, 2013:112). Tahap prediction (prediksi) merupakan suatu proses membuat dugaan suatu kejadian. Tahap ini siswa diminta guru untuk membuat suatu dugaan, selanjutnya siswa memberikan alasan dari dugaanya. Proses ini siswa diberi kebebasan untuk menyusun dugaan dengan alasanya, semakin banyak dugaan maka guru dapat mengetahui konsep dan pemikiran siswa tentang permasalahan yang diberikan.

Observation (observasi), dimana siswa akan menggunakan semua indra. Tahap ini siswa diminta melakukan praktikum atau demonstrasi, tujuannya untuk menguji kebenaran atas prediksi yang disampaikan. Apabila siswa melakukan praktikum diharapkan terjadi keseimbangan antara konsep yang diperoleh di awal dengan keterampilan yang dipraktikkan. Praktikum dilaksanakan dengan bimbingan guru dan sesuai langkah atau prosedur kerja yang ditetapkan pada jobsheet.

Explain (menjelaskan), siswa diminta membuat penjelasan tentang kesesuaian dugaan dengan hasil praktikum pada tahap observasi. Apabila hasil prediksi di awal sesuai hasil observasi dan setelah siswa memperoleh kebenaran atas prediksinya, maka siswa yakin akan konsepnya. Sedangkan jika siswa tidak 
tepat dalam memprekdiksi awal, maka siswa dapat mencari penjelasan atas ketidaktepatan prediksinya. Siswa secara acak dari masingmasing kelompok akan ditunjuk untuk melakukan presentasi di depan kelas untuk menjelaskan hasil praktikum.

Model pembelajaran PRP merupakan salah satu model pembelajaran aktif. Active learning merupakan salah satu strategi belajar yang menuntut keaktifan dan partisipasi siswa dalam setiap kegiatan belajar seoptimal mungkin sehingga siswa mengubah tingkah lakunya secara efektif dan efisien (Hamdani, 2011:49).

Menurut Melvin Silberman (2013:228) model pembelajaran PRP bertujuan untuk melatih kecakapan dengan partner belajar, serta meyakinkan bahwa kedua partner dapat melaksanakan kecakapan atau prosedur. Hal ini berarti siswa dikelompokkan menjadi berpasang-pasangan. Model pembelajaran PRP lebih menekankan kerjasama antar siswa pada suatu kelompok praktek keterampilan tertentu. Siswa tidak hanya dituntut mengerti teori saja, namun siswa harus aktif dalam praktek keterampilan sebagai persiapan dalam kehidupan nyata (Wibawa, 2017).

Langkah-langkah pelaksanaan model pembelajaran PRP menurut Suprijono (2012:16) sebagai berikut: pertama, guru memilih salah satu keterampilan yang akan dipelajari oleh siswa. Kedua guru membentuk kelompok secara berpasangan. Setiap pasangan dibuat dua peran yaitu demonstrator dan pengamat. Ketiga, guru meminta kepada demonstrator untuk menjelaskan cara mengerjakan keterampilan yang telah ditentukan, sedangkan pengamat bertugas mengamati dan menilai penjelasan yang dilakukan demonstrator atau temannya.

Keempat, guru meminta pasangan untuk bertukar peran yaitu, demonstrator bertukar menjadi pengamat dan pengamat menjadi demonstrator. Selanjutnya meminta siswa untuk melakukan praktikum sampai semua keterampilan dapat dikuasai siswa. Kelima, guru meminta siswa mempresentasikan hasil praktikum di depan kelompok lain yang sudah ditentukan oleh guru.

Berdasarkan paparan di atas, maka tujuan dari penelitian ini: (1) mendeskripsikan tingkat hasil belajar ranah kognitif karena penerapan model pembelajaran POE; (2) mendeskripsikan tingkat hasil belajar ranah psikomotor karena penerapan model pembelajaran POE; (3) mendeskripsikan tingkat hasil belajar ranah kognitif karena penerapan model pembelajaran PRP; (4) mendeskripsikan tingkat hasil belajar ranah psikomotor karena penerapan model pembelajaran PRP; (5) mengetahui signifikansi perbedaan rata-rata hasil belajar siswa ranah kognitif Simulasi dan Komunikasi Digital karena penerapan model pembelajaran POE dibandingkan dengan model pembelajaran PRP; dan (6) mengetahui signifikansi perbedaan rata-rata hasil belajar siswa ranah kognitif Simulasi dan Komunikasi Digital karena penerapan model pembelajaran POE dibandingkan dengan model pembelajaran PRP.

\section{METODE}

Penelitian ini merupakan jenis penelitian eskperimen. Desain rancangan penelitian yang digunakan adalah rancangan eksperimen semu tipe Non-Equivalent Control Group Design. Sebelum diberikan perlakuan, penelitian ini akan diuji kesetaraan kelas dahulu. Tujuannya untuk melihat apakah kelas yang akan digunakan untuk eksperimen sudah memiliki rata-rata kemampuan awal yang sama atau belum.

Data kemampuan awal yang digunakan adalah nilai KD sebelumnya yang diperoleh dari guru Simulasi dan Komunikasi Digital. Nilai kemampuan awal tersebut menjadi nilai pretest.

Objek penelitian ini adalah siswa kelas X TKJ pada semester 2 tahun ajaran 2017/2018 di SMKN 10 Malang. Sedangkan subjek yang digunakan adalah: (1) kelompok A yaitu kelas $\mathrm{X}$ TKJ 1 akan diberi perlakuan model POE; dan (2) kelompok B yaitu kelas X TKJ 4 akan diberi perlakuan model PRP.

Instrumen penelitian yang digunakan adalah instrumen perlakuan dan instrumen pengukuran. Instrumen perlakuan terdiri dari silabus, RPP, materi pembelajaran, media pembelajaran, dan jobsheet. Sedangkan instrumen pengukuran pada penelitian ini yaitu posttest untuk kognitif dan lembar observasi untuk psikomotor.

Tahapan analisis data yang dilakukan meliputi analisis deskriptif, uji prasyarat, uji kesamaan rata-rata awal, dan uji hipotesis. Tahap analisis deskriptif, dilakukan perhitungan kategori skor ideal, sehingga diperoleh rentangan nilai ranah kognitif dan ranah psikomotor.

Tahap uji prasyarat terdiri dari uji normalitas dan uji homogenitas. Uji normalitas menggunakan uji One Sample Kolmogorov 
Smirnov. Sedangkan uji homogenitas menggunakan uji Levene's. Tahap ketiga yaitu uji kesamaan rata-rata awal siswa. Uji kesamaan rata-rata dan uji hipotesis yang digunakan adalah uji-t dengan menggunakan teknik Independent-Sample T Test.

\section{HASIL DAN PEMBAHASAN}

Terdapat 6 hasil penelitian dan pembahasan pada penelitian ini.

\section{A. Deskripsi Tingkat Hasil Belajar Ranah Kognitif Simulasi dan Komunikasi Digital karena Penerapan Model Pembelajaran POE.}

Model pembelajaran POE diterapkan pada kelompok A (X TKJ 1). Rata-rata kemampuan awal kelompok A sebesar 60,57. Setelah diberi perlakuan model pembelajaran POE, diperoleh rata-rata sebesar 82,79. Perolehan nilai rerata tersebut ditunjukkan pada Tabel 4.1 sebagai berikut.

Tabel 4.1 Nilai Kognitif Kelompok A Setelah Diberi Perlakuan

\begin{tabular}{cccccc}
\hline Interval Ideal & $\begin{array}{c}\text { Frekuensi } \\
\text { Lapangan }\end{array}$ & Persentase & Kategori & Rata-Rata & Kriteria \\
\hline $85-100$ & 16 & $57.14 \%$ & Sangat Tinggi & & Tinggi \\
$75-84$ & 8 & $28.58 \%$ & Tinggi & \\
$65-74$ & 2 & $7.14 \%$ & Sedang & & \\
$55-64$ & 2 & $7.14 \%$ & Rendah & \\
$40-54$ & - & $0 \%$ & Sangat Rendah & \\
\hline Total & 28 & $100 \%$ & & \\
\hline
\end{tabular}

Berdasarkan Tabel 4.1 dapat diketahui bahwa nilai ranah kognitif kelompok A setelah diberi perlakuan memiliki: (1) kategori sangat tinggi sebanyak 16 siswa; (2) kategori tinggi sebanyak 8 siswa; (3) kategori sedang sebanyak 2 siswa; (4) kategori rendah sebanyak 2 siswa; dan (5) idak terdapat siswa pada kategori sangat rendah.

Peningkatan ketuntasan pembelajaran pada kelompok A sebesar 78,57\%. Sebab peningkatan tersebut dikarenakan pemahaman konsep yang diperoleh siswa setelah diberi perlakuan meningkat. Pendapat ini didukung oleh penelitian Ma'rifatun (2014) bahwa model pembelajaran POE mampu memfasilitasi siswa untuk mengembangkan aktivitas mental dan fisik secara optimal, serta dapat meningkatkan pemahaman siswa.

Hasil pengamatan guru selama proses pembelajaran, peningkatan hasil belajar ranah kognitif disebabkan karena: (1) kegiatan pembelajaran berpusat pada siswa yaitu siswa menggali pengetahuan awal sendiri; (2) siswa
(3) siswa lebih percaya diri untuk mempresentasikan hasil di depan kelas.

Berdasarkan hasil penelitian diperoleh nilai rata-rata ranah kognitif kelompok $\mathrm{A}$ mengalami peningkatan yaitu nilai kemampuan awal termasuk kategori rendah, sedangkan posttest termasuk kategori tinggi. Adanya peningkatan hasil belajar ranah kognitif pada penelitian ini, didukung oleh hasil penelitian sebelumnya pada model pembelajaran POE. Hasil penelitian Herniati (2017) menunjukkan bahwa terdapat peningkatan hasil belajar ranah kognitif pada siswa dengan penerapan model pembelajaran POE.

\section{B. Deskripsi Tingkat Hasil Belajar Ranah Psikomotor Simulasi dan Komunikasi Digital karena Penerapan Model Pembelajaran POE.}

Rata-rata nilai ranah psikomotor kelompok A sebesar 86,43. Perolehan nilai rerata tersebut ditunjukkan pada Tabel 4.2 sebagai berikut. 
Tabel 4.2 Nilai Ranah Psikomotor Kelompok A

\begin{tabular}{|c|c|}
\hline $\begin{array}{l}\text { Frekuensi } \\
\text { Lapangan }\end{array}$ & Rata-Rata \\
\hline $\begin{array}{l}83-100 \\
72-82 \\
61-71 \\
50-60 \\
33-49\end{array}$ & $\begin{array}{l}\text { Sangat Tinggi } \\
\text { Tinggi } \\
\text { Sedang } \\
\text { Rendah } \\
\text { Sangat Rendah }\end{array}$ \\
\hline $100 \%$ & \\
\hline $\begin{array}{l}\text { Berdasarkan Tabel } 4.2 \text { dapat diketahui } \\
\text { bahwa rentang nilai ranah psikomotor pada } \\
\text { kelompok A memiliki: (1) kategori sangat tinggi } \\
\text { sebanyak } 25 \text { siswa; (2) kategori tinggi sebanyak } \\
3 \text { siswa; (3) kategori sedang tidak terdapat } \\
\text { siswa; (4) tidak terdapat siswa pada kategori } \\
\text { rendah; dan (5) tidak terdapat siswa pada } \\
\text { kategori sangat rendah. Nilai rata-rata ranah } \\
\text { psikomotor yang diperoleh kelompok A } \\
\text { termasuk kategori sangat tinggi. Hasil penelitian } \\
\text { ini didukung oleh penelitian Dewi (2016) yang } \\
\text { menjelaskan bahwa, rata-rata nilai hasil belajar } \\
\text { siswa ranah psikomotor yang diajar } \\
\text { menggunakan model pembelajaran POE } \\
\text { memperoleh nilai tinggi. } \\
\text { pertemuan dengan menggunakan jobsheet yang } \\
\text { berbeda namun saling berkaitan. Lembar } \\
\text { observasi yang digunakan pada kegiatan } \\
\text { praktikum terdiri dari } 3 \text { aspek yang memuat } 10 \\
\text { indikator. Aspek pertama yaitu persiapan, terdiri } \\
\text { dari indikator kehadiran, berseragam lengkap dan } \\
\text { rapi, menyiapkan alat dan bahan. Aspek kedua } \\
\text { yaitu proses, terdiri dari indikator kerjasama } \\
\text { kelompok, langkah-langkah pada jobsheet, } \\
\text { ketepatan waktu pengumpulan tugas. Aspek } \\
\text { ketiga yaitu hasil, terdiri dari indikator }\end{array}$ & $\begin{array}{l}\text { kesesuaian dengan topik, kreativitas, kesesuaian } \\
\text { konten, kesesuaian durasi. } \\
\text { Berdasarkan hasil pengamatan guru } \\
\text { selama proses kegiatan praktikum pada } \\
\text { kelompok A didapatkan: (1) tahap pengamatan } \\
\text { (observe), siswa melakukan kegiatan praktikum } \\
\text { dengan aktif dan antusias untuk membuktikan } \\
\text { prediksi awal (predict). Hal ini dibuktikan } \\
\text { dengan siswa aktif berdiskusi bertukar ide dan } \\
\text { pendapat. Pendapat ini sesuai dengan penelitian } \\
\text { Indriana (2015) bahwa POE salah satu } \\
\text { pendekatan pembelajaran yang melibatkan peran } \\
\text { aktif siswa selama proses pembelajaran; dan (2) } \\
\text { tahap presentasi hasil (explain), guru belum } \\
\text { menunjuk salah satu kelompok yang diminta } \\
\text { untuk presentasi, namun siswa antusias untuk } \\
\text { menampilkan hasil di depan kelas. } \\
\text { C. Deskripsi Tingkat Hasil Belajar Ranah } \\
\text { Kognitif Simulasi dan Komunikasi } \\
\text { Digital karena Penerapan Model } \\
\text { Pembelajaran PRP. } \\
\text { Model pembelajaran PRP diterapkan } \\
\text { pada kelompok B (X TKJ 4). Rata-rata } \\
\text { kemampuan awal kelompok A sebesar 63. } \\
\text { Setelah diberi perlakuan model pembelajaran } \\
\text { POE, diperoleh rata-rata sebesar 74,25. } \\
\text { Perolehan nilai rerata tersebut ditunjukkan pada } \\
\text { Tabel } 4.3 \text { sebagai berikut. }\end{array}$ \\
\hline
\end{tabular}

Tabel 4.3 Nilai Ranah Kognitif Kelompok B Setelah Diberi Perlakuan

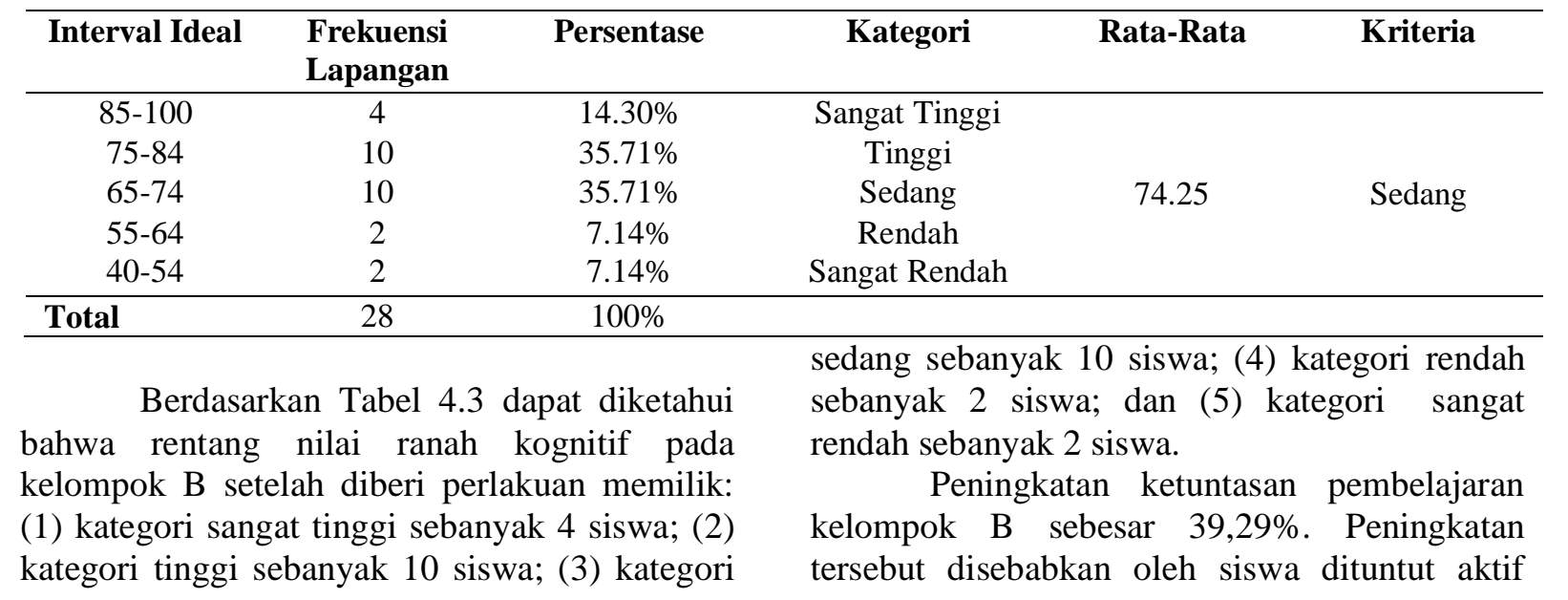




\section{3 | Jurnal Psikologi Pendidikan \& Konseling Vol. 4 No. 2 Desember 2018}

selama proses pembelajaran. Pendapat ini didukung oleh Sugandi (dalam Kristianingsih, 2010) yang menyatakan bahwa proses pembelajaran yang aktif akan membantu proses pembentukan pengetahuan, karena pengetahuan terbentuk dari diri dalam subyek belajar.

Hasil pengamatan guru selama proses pembelajaran, peningkatan hasil belajar ranah kognitif disebabkan karena: (1) siswa memperhatikan penjelasan dari guru sebelum mengerjakan tugas; (2) aktif berdiskusi bersama pasangan yang telah ditentukan oleh guru; (3) siswa berani bertanya apabila terdapat materi yang belum dipahami; dan (4) siswa percaya diri untuk mempresentasikan hasil di depan kelompok lain.

Hasil penelitian diperoleh nilai rata-rata ranah kognitif kelompok $\mathrm{B}$ mengalami peningkatan yaitu nilai kemampuan awal termasuk kategori rendah, sedangkan posttest termasuk kategori sedang. Adanya peningkatan hasil belajar ranah kognitif pada penelitian ini didukung oleh penelitian sebelumnya terhadap model pembelajaran PRP yang dilakukan oleh Putri (2018). Hasil penelitian menunjukkan bahwa model pembelajaran PRP dapat meningkatkan hasil belajar ranah kognitif siswa, sehingga dapat direkomendasikan sebagai alternatif model pembelajaran yang sesuai dengan pembelajaran SMK.

\section{Deskripsi Tingkat Hasil Belajar Ranah Psikomotor Simulasi dan Komunikasi Digital karena Penerapan Model Pembelajaran PRP.}

Rata-rata nilai ranah psikomotor kelompok A sebesar 86,43. Perolehan nilai rerata tersebut ditunjukkan pada Tabel 4.4 sebagai berikut.

Tabel 4.4 Nilai Ranah Psikomotor Kelompok B

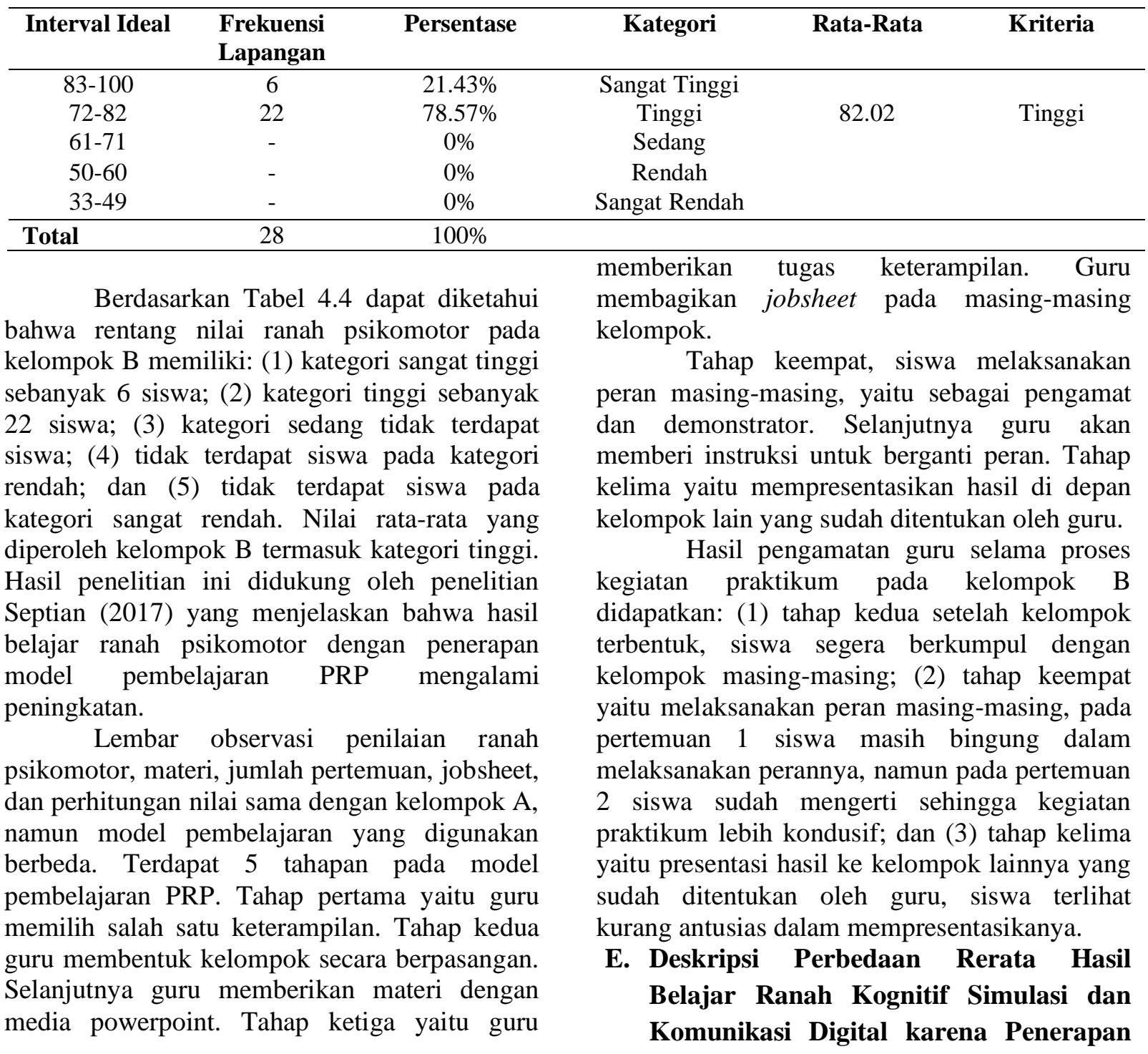




\section{Model Pembelajaran POE Dibandingkan dengan Model Pembelajaran PRP.}

Uji hipotesis pertama adalah melihat signifikansi perbedaan rerata hasil belajar ranah kognitif. Hasil uji hipotesis menunjukkan bahwa signifikansi ranah kognitif kelompok A dan kelompok B sebesar 0,006. Nilai signifikansi tersebut jauh di bawah 0,05 , maka $\mathrm{H}_{0}$ ditolak yang artinya terdapat signifikansi perbedaan rerata hasil belajar Simulasi dan Komunikasi Digital ranah kognitif karena penerapan model pembelajaran POE dibandingkan dengan model pembelajaran PRP.

Hasil belajar ranah kognitif diambil dari nilai posttest. Nilai rata-rata kelompok $\mathrm{POE}$ lebih unggul dari kelompok PRP. Hal ini disebabkan karena sintaks pembelajaran model POE terdapat tahap prediksi (predict). Tahap ini siswa diminta berdiskusi untuk bertukar ide dan pendapat bersama kelompok masing-masing untuk menggali pengetahuan awal mengenai permasalahan yang diberikan oleh guru. Selanjutnya pada tahap pengamatan, siswa diminta melakukan kegiatan praktikum untuk membuktikan prediksi awal, sehingga siswa dapat mengetahui teori yang benar setelah mengaplikasikannya. Hal ini sesuai pendapat Lestari (2017) yang mengungkapkan bahwa pengetahuan awal siswa sebelum praktikum akan menjadi dasar pembentukan keterampilan.

Menurut Atriyanti (2014) kelebihan model pembelajaran POE antara lain: (1) dapat membuat pelajaran menjadi lebih jelas dan konkret dengan meminta siswa menggali pengetahuannya sendiri atas apa yang dia tahu serta diperkuat oleh hasil pengamatan yang dilakukan; (2) siswa lebih mudah memahami apa yang dipelajari; (3) proses pembelajaran lebih menarik; dan (4) siswa dirangsang untuk aktif mengamati, menyesuaikan antara teori dengan kenyataan.

\section{F. Deskripsi Perbedaan Rerata Hasil Belajar Ranah Psikomotor Simulasi dan Komunikasi Digital karena Penerapan Model Pembelajaran POE Dibandingkan dengan Model Pembelajaran PRP.}

Uji hipotesis kedua adalah melihat signifikansi perbedaan rerata hasil belajar ranah psikomotor. Hasil uji hipotesis menunjukkan bahwa signifikansi ranah psikomotor kelompok A dan kelompok B sebesar 0,000. Nilai signifikansi tersebut jauh di bawah 0,05, maka $\mathrm{H}_{0}$ ditolak yang artinya terdapat signifikansi perbedaan rerata hasil belajar Simulasi dan
Komunikasi Digital ranah psikomotor karena penerapan model pembelajaran POE dibandingkan dengan model pembelajaran PRP.

Nilai rata-rata hasil belajar ranah psikomotor kelompok POE lebih unggul dari kelompok PRP. Hasil belajar ranah psikomotor diperoleh dari lembar observasi yang terdiri dari 3 aspek yaitu persiapan, proses, dan hasil. Berdasarkan analisis indikator dari ketiga aspek tersebut, dapat diketahui bahwa kelompok model pembelajaran POE lebih unggul 6 indikator dari total 10 indikator dibandingkan kelompok model pembelajaran PRP.

Hal ini dikarenakan siswa pada kelompok POE: (1) ketika mengerjakan tugas praktikum yang diberikan oleh guru, siswa aktif bertukar ide atau gagasan dengan kelompok masing-masing; (2) karakteristik siswa yang aktif bekerjasama dalam kelompok tidak individualis; (3) pengembangan jobsheet pada tugas praktikum yang diimplementasikan oleh masing-masing kelompok cukup banyak; dan (4) ketelitian siswa dalam membaca ketentuan tugas praktikum pada jobsheet.

\section{SIMPULAN DAN SARAN}

Berdasarkan hasil dan pembahasan yang telah diuraikan, maka diperoleh kesimpulan sebagi berikut: Pertama, hasil belajar ranah kognitif karena penerapan model pembelajaran POE menunjukkan adanya peningkatan dari kategori rendah menjadi tinggi. Kedua, hasil belajar ranah psikomotor karena penerapan model pembelajaran POE termasuk kategori sangat tinggi. Ketiga, hasil belajar ranah kognitif karena penerapan model pembelajaran PRP menunjukkan adanya peningkatan dari kategori rendah menjadi sedang. Keempat, hasil belajar ranah psikomotor karena penerapan model pembelajaran PRP termasuk kategori tinggi.

Kelima, terdapat perbedaan signifikan rata-rata hasil belajar siswa ranah kognitif pada kelompok model pembelajaran POE dengan kelompok model pembelajaran PRP. Keenam, terdapat perbedaan yang signifikan rata-rata hasil belajar siswa ranah psikomotor pada kelompok model pembelajaran POE dengan kelompok model pembelajaran PRP.

Berdasarkan hasil penelitian yang dilakukan, maka dapat diberikan saran yaitu sebaiknya perlu adanya penelitian lebih lanjut terhadap faktor-faktor yang dapat mempengaruhi hasil belajar dengan penerapan model pembelajaran POE dan model 
pembelajaran PRP pada mata pelajaran dan subjek penelitian yang berbeda.

\section{DAFTAR RUJUKAN}

Atriyanti, Y. \& Hadisaputro, S. 2015. Penerapan Model Pembelajaran POE untuk Meningkatkan Ketercapaian Kompetensi Dasar Siswa. Chemistry in Education, 4 (1). Diperoleh dari https://journal.unnes.ac.id/sju/index.php/c hemined/article/view/3566.

Hamdani, M.A. 2011. Strategi Belajar Mengajar. Bandung: Pustaka Setia.

Herniati, R., Sulistri, E., \& Rosdianto, H. 2017. Penerapan Model Predict Observe Explain dengan Pendekatan Learning By Doing untuk Meningkatkan Hasil Belajar Siswa. Jurnal Fisika FLUX, 14 (2), ISSN: 2514-1713. Diperoleh dari https://www.researchgate.net/publication/ 324055020.

Indriana, V., Arsyad, N., \& Mulbar, U. 2015. Penerapan Pendekatan Pembelajaran POE untuk Meningkatkan Kemampuan Berpikir Kreatif Siswa Kelas XI IPA-1 SMAN 22 Makassar. JURNAL DAYA MATEMATIS, 3 (1). Diperoleh dari http://ojs.unm.ac.id/JDM/article/view/131 7/pdf_5.

Kristianingsih, D.D., Sukiswo S.E., \& Khanafiyah, S. 2010. Peningkatan Hasil Belajar Siswa Melalui Model Pembelajaran Inkuiri dengan Metode Pictorial Riddle pada Pokok Bahasan Alat-Alat Optik di SMP. Jurnal Pendidikan Fisika Indonesia 6, ISSN: 1693-1246. Diperoleh dari http://journal.unnes.ac.id.

Lestari, U., Astalini., \& Darmaji. 2017. Deskripsi Keterampilan Proses Sains Mahasiswa Pendidikan Fisika Universitas Jambi pada Kegaiatn Praktikum Fisika Dasr I. Jurnal Fisika. Diperoleh dari http://repository.unja.ac.id.

Ma'rifatun, Martini, K.S., \& Utomo, S.B. 2014. Pengaruh Model Pembelajaran Predict Observe Explain (POE) Menggunakan Metode Eksperimen dan Demonstrasi Terhadap Prestasi Belajar Siswa pada Pokok Bahasan Larutan Penyangga Kelas XI SMA Al Islam 1 Surakarta Tahun Pelajaran 2013/2014. Jurnal Pendidikan Kimia, 3 (3) , ISSN: 2337-9995. Diperoleh dari http://jurnal.fkip.uns.ac.id/kimia.

Muna, I.A. 2017. Model Pembelajaran POE (Predict-Observe-Explain) dalam Meningkatkan Pemahaman Konsep dan Keterampilan Proses IPA. Jurnal Studi Agama, 5 (1), ISSN: 2527631X. Diperoleh dari

http://ejournal.kopertais4.or.id/mataraman /index.php/washatiya/article/download/30 28/2258/.

Putri, A. P., Edidas, E., \& Dewi, I.P. 2018. Pengaruh Model Active Learning Tipe Practice Rehearsal Pairs terhadap Hasil Belajar Siswa X TKJ dalam Mata Pelajaran Simulasi Digital di SMK Negeri 3 Pariaman. VOTEKNIKA,.6 (1). Diperoleh dari https://ejournal.unp.ac.id.

Putro, S.C. \& Desynatria, W. 2016. Interaksi antara Faktor Inisiatif dengan Faktor Penerapan Model Konstruktivistik Pengaruhnya Terhadap Hasil Belajar Teknologi pada Siswa SMK. JURNAL TEKNO, 26 (2).

Septian, D. 2017. Penerapan Model Pembelajaran Kooperatif Tipe Practice Rehearsal Pairs dengan AUTOCAD 3D pada Mata Pelajaran Menggambar dengan Perangkat Lunak di SMKN 2 Suarabaya. Jurnal Kajian Pendidikan Teknik Bangunan, 2 (2), 237-240. Diperoleh dari https://jurnalmahasiswa.unesa.ac.id.

Silberman, M.L. 2013. Active Learning: 101 Strategi Pembelajaran Aktif. Yogyakarta: Insan Madani.

Suparno, P. 2013. Metodologi Pembelajaran Fisika Konstruktivistik \& Menyenangkan. Yogyakarta: Universitas Sanata Dharma Yogyakarta.

Suprijono, A. 2012. Cooperative Learning, Teori \& Aplikasi PAIKEM. Yogyakarta: Pustaka Pelajar.

Wibawa, R. 2017. Pengaruh Pembelajaran Practice Rehearsal pada Mata Kuliah Media Tiga Dimensi Terhadap Kreativitas Belajar Mahasiswa di Jurusan Teknologi Pendidikan. Jurnal Teknologi Pendidikan, 2 (1). Diperoleh dari http://fip.ikipmataram.ac.id. 